Proc. Estonian Acad. Sci. Eng., 2001, 7, 2, 157-173

\title{
WAVE REGIMES AND ANOMALIES OFF NORTH-WESTERN SAAREMAA ISLAND
}

\author{
Tarmo SOOMERE
}

Estonian Marine Institute, Paldiski mnt. 1, 10137 Tallinn, Estonia; tarmo@phys.sea.ee

Received 27 February 2001, in revised form 22 March 2001

\begin{abstract}
Properties of the saturated wave field in the neighbourhood of possible sites of the Saaremaa deep harbour during typical (about $15 \mathrm{~m} / \mathrm{s}$ ) and extreme (about $25 \mathrm{~m} / \mathrm{s}$ ) storms, forced by steady winds, are analysed on the basis of the wave model WAM. The toughest wave regime is at Undva (Uudepanga Bay, probability of occurrence of waves exceeding $3 \mathrm{~m}$ is $1 \%$ ), slightly better at Suuriku-Kuriku $(0.6 \%)$ and the mildest at Vaigu $(0.13 \%)$. Directional distribution of wave heights in typical and extreme storms is highly anisotropic. The highest waves correspond to NNW storms. Remarkable wave height anomalies may occur in the neighbourhood of the harbour sites. The anomalies emerge only during very strong storms and may serve as a major navigation danger.
\end{abstract}

Key words: wave modelling, local wave climate, surface waves, wave height anomalies.

\section{INTRODUCTION}

Wind waves form the primary visible and active structure of the ocean surface which directly interacts with the interests of society and its members. The interactions are typically neutral, sometimes desirable (vertical ventilation of water masses supporting life in deep waters) but at times may become highly inconvenient (destruction of beaches, pollution transport, damaging of harbour objects, breaking of dams) or even fatal (shipwrecking, misfortunes by swimming in high waves).

During the last decades, a great deal of interest has been paid to investigations into wind waves and general features of interactions between the water surface and the atmosphere $\left[^{1,2}\right]$. However, until now, no systematic studies of surface waves in Estonia have been performed except visual tracking of wave heights at several sites and compiling a wave atlas in 1960s $\left[^{3,4}\right]$. It is well known that wind waves in the Baltic Sea are typically shorter and steeper than open ocean waves and thus more dangerous to ships. Many events suggest that wave regime 
anomalies may occur during specific time intervals and in particular areas. A number of factors, essentially modifying wave field in the ocean, are feeble in the Baltic Sea. Tidal currents, causing at times extremely complex wave regimes $\left[{ }^{5}\right]$, are negligible. Propagation of the wave fields over current rings may cause an essential steepening of waves $\left[{ }^{6,7}\right]$, but synoptic-scale structures are much less intense in the Baltic Sea than in open ocean. The seabed is mostly rocky or sandy and the effect of its movements $\left.{ }^{8,9}\right]$ as well as the effect created by an elastic bottom $\left[{ }^{10,11}\right]$ are evidently negligible.

An explanation of the odd steepness of the Baltic Sea waves, referring to small depth of the basin, is not always appropriate. The depth of the Baltic Proper is typically over $100 \mathrm{~m}$ and topographic effects play a certain role only in the coastal zone with depth under $\left.20-30 \mathrm{~m} \mathrm{[}^{2}\right]$. A possible explanation is that the wave field in the Baltic Sea is mostly "young" and contains a large portion of higher harmonics. Equivalently, the energy maximum is located in relatively short waves and the typical slope of wave fronts is steeper as compared to open ocean waves. Another reason could be the specific anisotropy of the wind regime and the possibility of uniform storms in the area in question $\left[{ }^{12,13}\right]$.

Typical and extreme wave regimes and their directional properties are of primary interest in navigation and harbour design. Extreme wave regimes at the harbour site basically define the harbour configuration, height of breakwaters and quays, as well as demands to the stability of the constructions. In the current study, properties of the wave field during typical and extreme storms in the neighbourhood of three possible sites of the Saaremaa deep harbour $\left.{ }^{[4,15}\right]$ are analysed. Sections 2 and 3 describe implementation of the wave model WAM $\left[^{2}\right]$ for the Baltic Sea. Section 4 discusses main properties of growth and saturation of wave fields during typical storms occurring many times every year. Critical and extreme wave heights and their directional distributions are analysed in Section 5. Section 6 demonstrates that remarkable wave height anomalies may occur in the neighbourhood of the harbour sites.

\section{WAVE MODEL WAM}

The third-generation model WAM $\left[{ }^{2}\right]$ for the first time systematically includes main effects affecting ocean wave generation and dissipation as well as nonlinear interactions between wave harmonics. It has been carefully tuned for modelling the open ocean conditions $\left[^{2}\right]$ and is run routinely for wave forecasting and hindcasting by several dozens of users. A distinguishing feature of the model is that the code is open and new users are welcome. Third generation spectral wave models work with full two-dimensional wave spectrum and reasonably estimate non-linear energy exchange between wave harmonics. Some specific models take into account energy exchange in wave triads that is important in shallow water problems $\left[{ }^{16}\right]$. Given the wave spectrum, it is straightforward to calculate traditional properties of wave fields. Since these models are statistical, 
tracking of a single wave component (as dynamic wave models do $\left[{ }^{17}\right]$ ) is impossible.

The fundamental drawback of earlier models is that they take into account a small number of wave field parameters. Typically, only mean wave height (or significant wave height), mean (or peak) period, and direction are calculated assuming that the wind speed and direction are constant. (Significant wave height is the average height of the highest third of waves. It is used below for characterizing the wave fields if not stated otherwise.) Since such models describe remarkably well wave parameters at open sea (provided wind is more or less steady) as well as the behaviour of monochromatic wave fields on spatially varying topography, many of them are in use for specific cases. However, they fail to describe wave fields in large basins during spatially and temporally nonuniform storms. Also, they are not able to describe non-linear processes within the wave field that are responsible for the generation of long waves and swell.

Application of the third generation wave models for the Baltic Sea is not straightforward since they cannot resolve interactions between steep (strongly non-linear) waves and give a relatively large error for shallow water waves. They fail in describing steep wave propagation against currents and do not take into account the interaction of waves with vertically structured currents. Also, geometrical form of the Baltic Sea is extremely complex. Nevertheless, the standard WAM model works reasonably well for the Baltic Proper $\left[{ }^{18}\right]$.

The current version (cycle 4) of the WAM model takes into account the following factors affecting wave generation, evolution, and dissipation: coastal line of the basin, topographic refraction, spatial and temporal variation of wind properties, wave propagation on the sea surface, non-linear quadruplet interaction between wave harmonics, whitecapping, shoaling, wave dissipation in shallow areas due to bottom friction, and interaction between waves and stationary currents. The model is based on the transport equation

$$
\frac{\partial}{\partial t} N+\frac{\partial}{\partial z_{i}}\left(\dot{z}_{i} N\right)=S_{i n}+S_{n l}+S_{d s}+S_{b o t}
$$

for the two-dimensional wave action density spectrum $N=N\left(x_{1}, x_{2}, k_{1}, k_{2}, t\right)$. Here $x_{1}, x_{2}$, and $t$ are the spatial co-ordinates and time, $k_{1}$ and $k_{2}$ are components of the wave vector, and $\dot{z}$ is the (generalized) propagation velocity of a wave group in the four-dimensional phase space $z=\left(x_{1}, x_{2}, k_{1}, k_{2}\right) \in$ $\boldsymbol{R}^{2}\left(x_{1}, x_{2}\right) \times \boldsymbol{R}^{2}\left(k_{1}, k_{2}\right)$. The first term on the left-hand side of Eq. (1) describes temporal evolution of the wave field. The second term describes changes of the wave components due to advection in the framework of geometrical optics (wave propagation on the sea surface, refraction due to bottom topography and currents). The right-hand side includes wave generation processes $\left(S_{\text {in }}\right)$, nonlinear interaction $\left(S_{n l}\right)$, dissipation processes $\left(S_{d s}\right)$, and changes in wave energy 
due to the bottom friction $\left(S_{b o t}\right)$. Model physics and approximations are in detail described in $\left[^{2}\right]$.

\section{COARSE AND NESTED WAVE MODELS FOR THE BALTIC SEA}

Since the WAM model was first implemented for wave studies in Estonia in the framework of the hydrodynamical studies of the possible harbour sites $\left[{ }^{14,19}\right]$, we describe its implementation in some detail. The standard model code operates at the present time on Win95, Win98, and Windows NT platforms. Results of a test run in a rectangular basin with the wind field taken from the historical SWAMP experiment were identical with those of the standard model $\left[^{2}\right]$. Also, wave properties predicted by the model for simple basins and uniform wind fields differed less than by $5 \%$ from those predicted by parametric models.

The model bathymetry is based on data prepared by the Institut für Ostseeforschung, Warnemünde $\left[{ }^{20}\right]$, with spatial resolution 1' along latitude and 2 ' along longitude. Grid points corresponding to an area consisting of more than $1 / 3$ of land, areas with depth less than $1 \mathrm{~m}$ as well as several small isolated islands (Ruhnu, Kihnu, Suursaar, Kassari) are interpreted as land points. This approximation is justified in studies of global wave patterns and extreme wave regimes since islands and shallow areas effectively block wave propagation.

Since the coastal line of the Baltic Sea is pretty ragged and contains a number of semi-isolated basins, coastal area of the grid was smoothed manually, partially with the use of (formerly classified) maps by USSR Ministry of Defence and public maps by Estonian National Maritime Board. Sea points corresponding to semi-enclosed fjords that weakly contribute to the global wave field were recurrently excluded. Differently from circulation models, sea points corresponding to widely open small bays were kept since they may provide an increase of the fetch length.

The resulting coastal line model generalizes the fine structure of the coast of Finland but roughly retains its geographical location. The southern coast of the Gulf of Finland is represented with an acceptable accuracy. Naissaar remains island whereas Kurkse Strait is closed. The Moonsund region suffers from certain distortion of the coastal line. Vormsi, Muhu, and Kassari are represented as peninsulas, Kihnu and Ruhnu are slightly overestimated in size. However, for the purposes of the current study, wave regime in the Gulf of Riga and Moonsund area is unimportant. The relatively smooth southern coast of the Baltic Proper and Arcona basin is fairly well represented. Rügen reduces to a peninsula that is clearly justified. Influence of certain distortions of the Danish coastal line on the wave field in Central Baltic is evidently negligible. Gotland is well represented but the western coast of the Baltic Proper suffers from certain distortion (that is less than $1 \%$ from the total extension of the Baltic Proper and evidently negligible). 


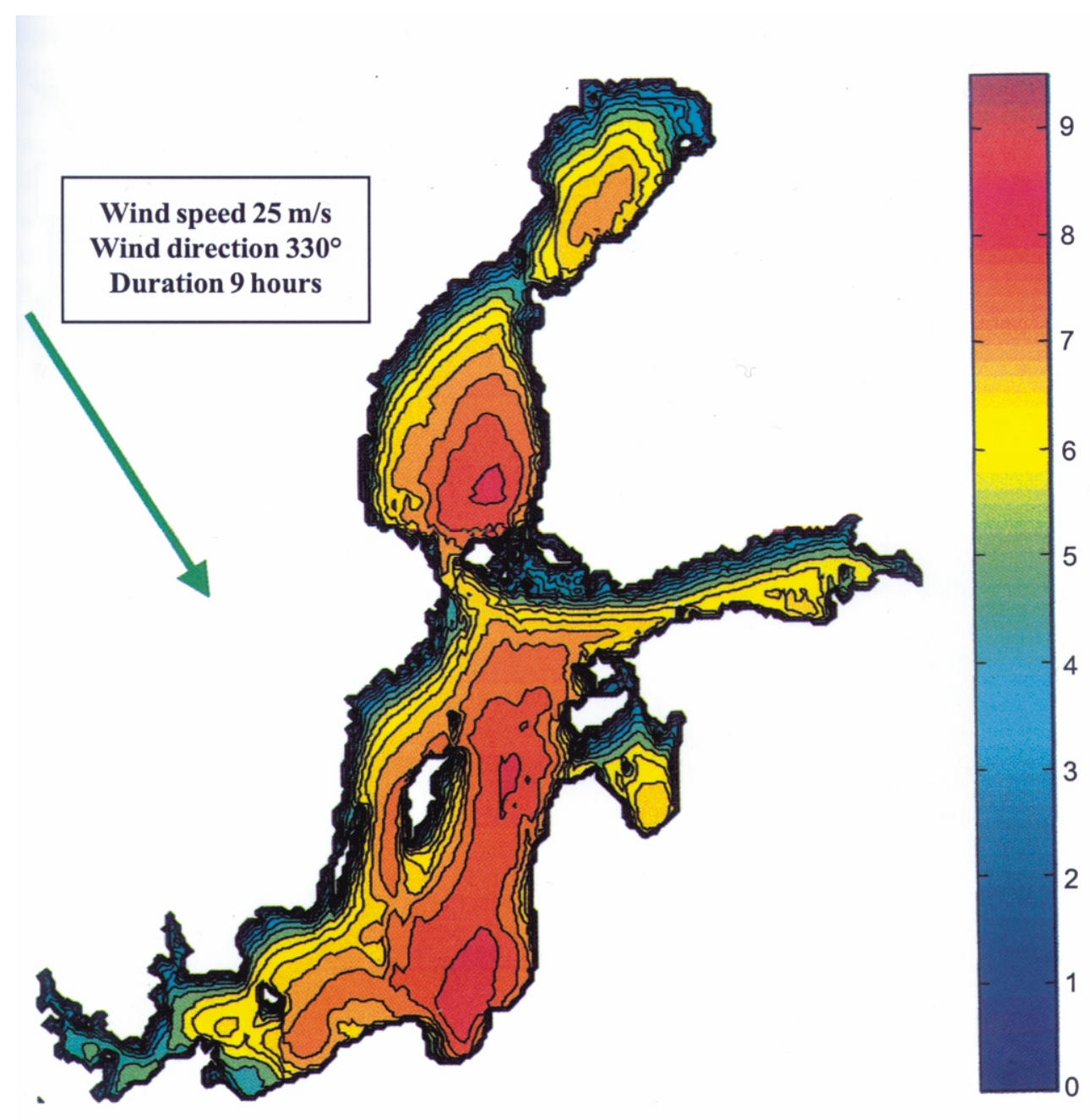

Fig. 1. Significant wave heights in the Baltic Sea in the case of an extreme NNW storm. Maximum wave heights $8.9 \mathrm{~m}$ are in the southern part of the Baltic Proper. Contour line interval is $0.5 \mathrm{~m}$. 



Fig. 2. Significant wave heights (m) in the coastal zone of Saaremaa and Hiiumaa in the case of an extreme NNW storm. Maximum wave heights are $9.8 \mathrm{~m}$ on the Harilaiu Bank. Units of the axes are in nautical miles. Contour line interval is $0.5 \mathrm{~m}$. 
Generally, boundary conditions representing far wave field in local area models constitute the most delicate problem since long waves may cross enormous spans. As different from circulation models that definitely request boundary conditions for Danish Straits, the straits effectively block the surface wave energy. The Small Belt is narrow and bendy and it indeed blocks the wind wave propagation. Öresund is relatively wide and might serve as a wave channel if it were straight. However, it bends and the southern part of Sweden blocks the wave energy. Waves propagating through Great Belt may have minor influence southwards the strait but evidently not in the Baltic Proper. The fact that the Baltic Sea is closed in the framework of wave propagation, essentially simplifies the wave prediction problem.

Ignoring Gulf of Finland probably would not essentially change the wave field in the coastal zone of Saaremaa. However, doing this would give a minor advance in computational speed but would need extensive test calculations. Although the wave regime in Bothnian Sea does not directly influence wave properties at the harbour sites, its southern part provides an extended fetch length for certain wind directions. The presence of currents was ignored since there are no intense stationary currents in the area in question and the current pattern is essentially modified by the local wind regime and water level $\left[{ }^{19}\right]$.

A two-step model was used in the computations. Firstly, a coarse-resolution model was run for the whole Baltic Sea. It has a regular rectangular grid (step 3' along latitude and 6' along longitude) with resolution about $3 \times 3$ nautical miles. The coarse grid size is $239 \times 208$, it extends from $9.6^{\circ}$ to $30.30^{\circ} \mathrm{E}$ and from $53.95^{\circ}$ to $65.85^{\circ} \mathrm{N}$ (Fig. $1^{*}$ ) and contains 11545 sea points. At each sea point of both models, 300 components of the two-dimensional spectrum (12 directions, 25 frequencies) were computed. Computation of the wave field is stable; both the propagation and the source time steps are $\leq 3 \mathrm{~min}$. The coarse model predicts with an acceptable accuracy wave properties at open sea (Fig. $1^{*}$ ) but fails to describe small-scale topographic effects and transformation of wave patterns near the coastal line.

Many bottom inhomogeneities of the coastal zone of Saaremaa and Hiiumaa (Harilaiu Bank, Mustkuiv Bank and Suurkuiv Bank near Vilsandi, Neupokojev Bank, and Kolga Bank near Ristna Peninsula) and features of the coastal line have a characteristic horizontal scale 1-3 mi. For that reason, secondly, the model was run on the nested grid (step 1' along latitude and 2' along longitude, resolution about $1 \times 1 \mathrm{mi}, 3277$ sea points) covering an area of $110 \times 110 \mathrm{~km}$ in the coastal zone of Saaremaa and Hiiumaa. Wave properties at the open boundaries of the nested grid were taken from the coarse runs. The nested model reasonably predicts wave properties at about $1 \mathrm{~km}$ off the coast (Fig. $2^{*}$ ).

In order to avoid time interpolation of the boundary data (a major source of instability of multi-step schemes), time step $1 \mathrm{~min}$ for both models was used. (Coupling of models with different temporal and spatial resolution is analysed

\footnotetext{
* Asterisks mark the coloured figures on unnumbered inserts.
} 
in $\left[{ }^{19}\right]$ from the viewpoint of multi-step current modelling.) Since WAM model fails to predict the wave field in the coastal zone, nearshore wave transformation at the harbour sites was estimated with the use of NSW and BW modules from the MIKE21 software package $\left[{ }^{17}\right]$.

\section{WIND SPEED IN TYPICAL AND EXTREME STORMS}

In the coastal zone of the NW part of Saaremaa, the wave field evidently is fetch-limited: the maximum fetch is about $200 \mathrm{~km}$ for NW winds and only a few tens of kilometers for NE and east winds. Thus, wave field at the possible harbour sites saturates relatively fast even during very strong winds. Here saturation means that wave generation and dissipation processes are integrally balanced and the possibility of spectral changes that may last considerably longer (for example, generation of long waves and swell) is ignored. Indeed, the typical saturation time is $6-8 \mathrm{~h}$ for the directions with the longest fetch (Fig. 3).

Since turning wind and fluctuating wind speed generally lead to decrease in wave amplitudes $\left[^{2}\right]$, extreme wave properties near harbour sites (see inside back cover) are delimited by wind direction and maximum speed in uniform storms lasting, at least, for $6 \mathrm{~h}$. The wind data from coastal meteorological stations (originally filed every $3 \mathrm{~h}$ ) were available with time interval of $6 \mathrm{~h}\left[^{12,13}\right]$. Thus each record in the data may be interpreted as representing mean wind speed and direction within $\pm 3 \mathrm{~h}$ from the measurement instant. Below it will be demonstrated that steady wind with duration of $6 \mathrm{~h}$ mostly brings the sea state close to the saturated regime. Consequently, extreme wave properties can be found with an acceptable accuracy from a set of runs with a steady wind field. Another argument for using only constant wind fields is that storms in which wind speed and direction are constant over large areas and during a long time frequently occur in the Baltic Proper $\left[{ }^{13}\right]$.

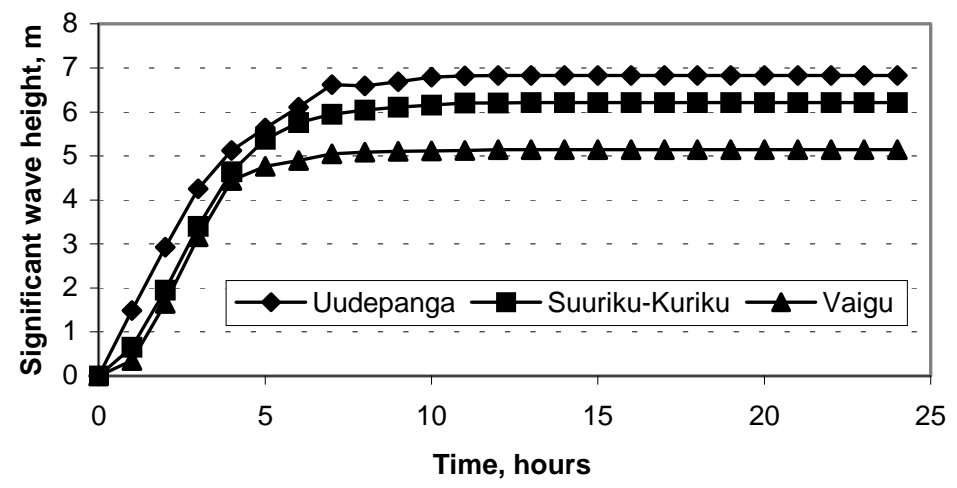

Fig. 3. Dependence of maximum significant wave heights on wind duration at the possible harbour sites. Wind direction is $315^{\circ}$ at Uudepanga Bay, $345^{\circ}$ at Suuriku-Kuriku, and $360^{\circ}$ at Vaigu. 
However, historical wind data should be used with a great care. For example, wind atlas published by the USSR hydrometeorological services shows that wind speed over $25 \mathrm{~m} / \mathrm{s}$ may frequently occur in the northern Baltic Proper and that even wind speed $35 \mathrm{~m} / \mathrm{s}$ is possible $\left.{ }^{4,21}\right]$. Vilsandi (1977-1991) and Näsudden (Gotland, 1980-1990) data show that maximum hourly mean wind speed may reach $25 \mathrm{~m} / \mathrm{s}$ once a decade. Most probably, extremely high wind speeds occur only in short and localized gusts. Extreme waves occur only if wind speed is high over a large area and during a long time. Comparison of Vilsandi and Näsudden data shows that Vilsandi data mostly represent well wind properties in the Baltic Proper $\left[{ }^{12,13}\right]$. Only east winds are somewhat weaker at Vilsandi than at open sea but the data still represent adequately east wind field between Saaremaa and Hiiumaa. For that reason, estimates of the frequency of strong storms and their directional distribution on the basis of Vilsandi data $\left[{ }^{12,13}\right]$ are used in wave regime assessments below.

Wind speeds under $10 \mathrm{~m} / \mathrm{s}$ are unimportant in the context of the study since they do not generate substantial wave heights. In the region in question, strong winds (in meteorology traditionally $>10 \mathrm{~m} / \mathrm{s}$ ) occur once a week. If wind speed reaches $15 \mathrm{~m} / \mathrm{s}$ (seven or eight days yearly, with probability $2 \%$ ), the resulting wave heights may exceed $3 \mathrm{~m}$. National maritime agencies confirm that significant wave heights at the regular passanger ro-ro ship lines, crossing the Baltic Sea, exceed 2.8-3.1 m with a probability of $10 \%$ in the northern Baltic Proper and 2.8-3.3 $\mathrm{m}$ in the whole Baltic Sea*. This measure is called critical wave height in ship engineering and is estimated for each particular ship route or aquatory. In what follows, it is assumed that critical wave height in the Baltic Proper is $3 \mathrm{~m}$.

Since many storms are relatively short, the frequency of occurrence of the mean wind speed over $15 \mathrm{~m} / \mathrm{s}$ is $10-20$ times yearly or once a month. Wind speed over $20 \mathrm{~m} / \mathrm{s}$ occurs about once a year. Wave heights generated by such storms exceed $5 \mathrm{~m}$ at open sea and may cause major navigation problems. The maximum wind speed recorded at Vilsandi during 1977-1991 is $25 \mathrm{~m} / \mathrm{s}$. Data reanalysis with the use of Weibull distribution shows that this wind speed generally occurs once in 20 years. Once in 50 years wind speed may exceed $26 \mathrm{~m} / \mathrm{s}$ and once in a century $27 \mathrm{~m} / \mathrm{s}\left[{ }^{13}\right]$. Notice that the presented data characterize mean wind speed during a few hours and not maximum wind speed in gusts.

Directional distribution of extreme wind speeds is drastically anisotropic $\left[{ }^{13}\right]$. Maximum NNW wind speed is $27 \mathrm{~m} / \mathrm{s}$ once a century whereas maximum east wind speed is only $11 \mathrm{~m} / \mathrm{s}$. Difference of wave heights at the open sea for extreme winds from different directions is astonishing. NNW winds may easily create wave heights over $10 \mathrm{~m}$ whereas wave heights due to east winds do not exceed $1.5 \mathrm{~m}$. In different harbour sites the rate of anisotropy may be even larger.

* This information is based on letters from the Marine Research Institute, Helsinki (19 Jan 1996), Estonian Meteorological and Hydrological Institute (19 Feb 1996), and Bundesamt für Seeschiffahrt und Hydrographie, Hamburg (14 Feb 1996). 


\section{TYPICAL WAVE HEIGHTS}

Traditionally, typical and maximum wave heights are calculated for a fixed wind speed notwithstanding the directional distribution of winds. Wave regime then depends only on geometrical factors such as fetch length, bottom topography, and the particular location of the harbour. Another technique takes into account the directional distribution of extreme wind speeds (that can be easily calculated from contemporary wind atlases $\left[{ }^{22}\right]$ ). For directionally homogeneous wind fields the methods coincide. However, the wind regime in the Baltic Proper is highly anisotropic $\left[{ }^{12,13}\right]$ and extreme wind speeds from different directions differ more than twice.

One might argue that the traditional concept is out of date as soon as the directional wind structure is at hand. There are, however, sound arguments for the traditional method. In many regions, the strongest vortex-like storms may blow from any direction although climatological wind rose is highly anisotropic. Climate warming is accompanied by ever-frequent occurrence of localized storms whose directional structure not necessarily matches the climatological directional distribution of extreme wind speeds. Since the fetch length for the harbour sites is relatively small, it is still reasonable to estimate maximum wave loads during such events. Another critical point is the reliability of the wind speed distribution for different directions. Since the number of wind recordings for each direction is much less than the total number of wind recordings, directional wind statistics may be erroneous.

The calculations were performed for wind speeds 15,20 , and $25 \mathrm{~m} / \mathrm{s}$ with angular resolution $15^{\circ}$. Since all the harbour sites are sheltered from the southern direction, wave properties were calculated only for winds from the northern sector. Only SWW winds may create considerable wave heights in Uudepanga Bay if they occur simultaneously with a high water level. Notice that the wave properties described below are computed at a distance of about $1 \mathrm{~km}$ from the harbour sites and correspond neither to the open sea nor to the coastal line.

During a typical storm (wind speed about $15 \mathrm{~m} / \mathrm{s}$ ), significant wave height in Uudepanga Bay reaches $2.5 \mathrm{~m}$ during $10 \mathrm{~h}$ for winds from a wide sector (NWW$\mathrm{NNO}$, directions $285^{\circ}-15^{\circ}$, Fig. 4). Only for NW winds wave heights continue to grow and after $12 \mathrm{~h}$ achieve saturation on the level of $2.8 \mathrm{~m}$. The reason is that the fetch is somewhat longer for NW winds since it starts already from the Bothnian Sea. For western directions, wave heights are clearly smaller since Kiipsaare Cape and the shallow area NW of the cape (Harilaiu Bank) shelters Uudepanga Bay to some extent. Since the bay is mostly open to the west, west wind $15 \mathrm{~m} / \mathrm{s}$ still causes wave heights about $2.2 \mathrm{~m}$. For NE winds, wave heights in the bay do not exceed $1.5 \mathrm{~m}$ due to sheltering effect of Undva Cape, whereas in the harbour area wave heights are even smaller. During east and south storms there are no considerable waves in the bay. 
Wind $15 \mathrm{~m} / \mathrm{s}$
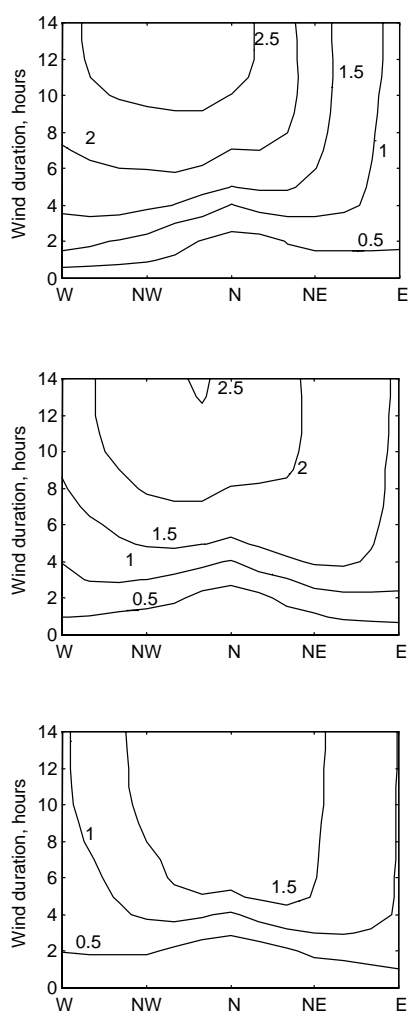

Wind $20 \mathrm{~m} / \mathrm{s}$
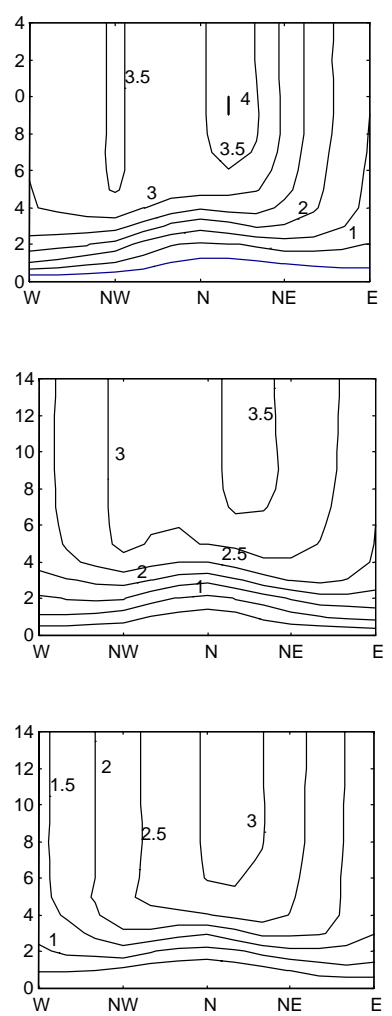

Wind $25 \mathrm{~m} / \mathrm{s}$
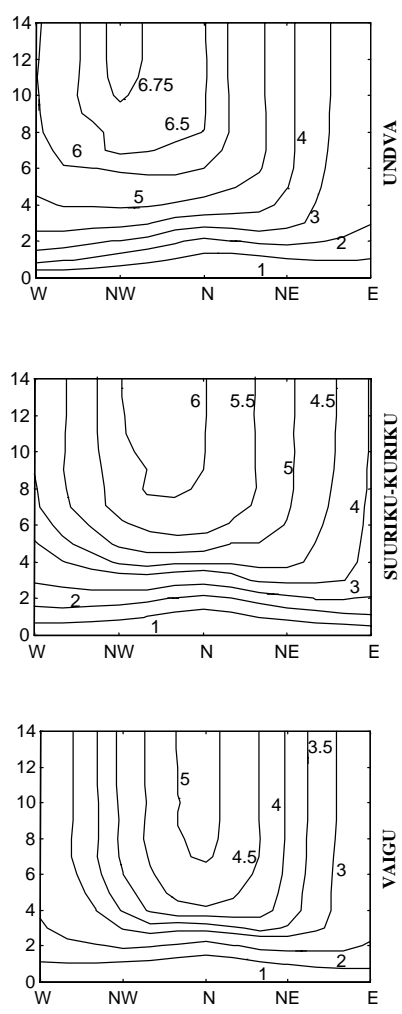

Fig. 4. Dependence of significant wave height (numbers at isolines, $m$ ) on the wind direction, speed, and duration at the harbour sites.

In the case of strong winds from the northern sector, wave heights near Suuriku-Kuriku (2.2-2.5 m) are comparable to wave heights in Uudepanga Bay. The directional distribution of saturated wave height differs from that in Uudepanga Bay. Suuriku-Kuriku is sheltered against waves coming from NW by the Suuriku Clint (the waves are additionally damped on a shallow area next to Suuriku Clint). NNW winds $\left(345^{\circ}\right)$ create the highest waves (over $2.5 \mathrm{~m}$ ) near Suuriku-Kuriku. For this particular direction, neither Suuriku Clint nor Hiiumaa shelter the harbour site. If wind turns from this direction either to west or east, wave heights near the harbour site decrease fast and do not exceed $1.5 \mathrm{~m}$ for east and west winds.

Wave heights near Vaigu are smaller than at other harbour sites. This is not surprising since Vaigu is open for NE winds that are relatively infrequent and weak. Only north winds from a narrow sector may create significant wave heights up to $1.8-2 \mathrm{~m}$ (Fig. 4). For all other wind directions, wave heights near the harbour sites are less than $1 \mathrm{~m}$. 


\section{CRITICAL AND EXTREME WAVE HEIGHTS}

The probability of critical wave heights near the harbour sites can be found from the distribution of wave heights created by winds with constant speed from different directions. Generally, critical wave heights may occur near the harbour sites if mean wind speed exceeds $16 \mathrm{~m} / \mathrm{s}$. At Undva, wave heights exceed $3 \mathrm{~m}$ for wind speeds over $16 \mathrm{~m} / \mathrm{s}$ from a wide sector from west to NE $\left(270^{\circ}-45^{\circ}\right.$, Fig. 4) with probability $1 \%$. At Suuriku-Kuriku, wave heights exceed $3 \mathrm{~m}$ for an equally wide sector but shifted to some extent to the eastern direction (directions $300^{\circ}-$ $75^{\circ}$ ), for wind speeds exceeding $17 \mathrm{~m} / \mathrm{s}$ with a probability of $0.6 \%$. The probability of critical wave heights in Uudepanga Bay exceeds that near SuurikuKuriku mainly because the frequency of NW storms is high $\left[{ }^{13}\right]$. The probabilities of occurrence of critical wave heights near Undva and Suuriku-Kuriku are comparable and such waves occur on 3-4 days annually. Values of the critical wave probability show that the harbour sites are well sheltered from open sea waves.

At Vaigu wave heights exceed $3 \mathrm{~m}$ with a probability of $0.13 \%$ only for very strong north winds (>19 $\mathrm{m} / \mathrm{s}$ ) from a narrow sector (directions $315^{\circ}-25^{\circ}$ ).

It is interesting to notice that wave heights at Undva are the highest for north winds if wind speed is $20 \mathrm{~m} / \mathrm{s}$, but for NW winds if wind speed is 15 or $25 \mathrm{~m} / \mathrm{s}$ (Fig. 4). The most probable reason for this feature is topographic refraction of open sea waves in the shallow areas on Kiipsaare Bank and at Undva Cape that has different influence on waves with different heights and periods.

Maximum wind speed once during 20 years calculated on the basis of the Weibull distribution for Vilsandi data is $25-26 \mathrm{~m} / \mathrm{s}\left[{ }^{13}\right]$. Wave fields at harbour sites corresponding to this wind speed demonstrate that the toughest wave regime is near Undva during extreme NW and north winds (Fig. 4). Significant wave heights in the central area of the Uudepanga Bay reach $6.8 \mathrm{~m}$ for NW winds and exceed $6 \mathrm{~m}$ during winds from relatively wide NW sector $\left(285^{\circ}-360^{\circ}\right)$. Wave heights reach $5.5 \mathrm{~m}$ during west storms and $4 \mathrm{~m}$ during SWW storms. At open sea, WAM model predicts extreme wave heights slightly exceeding $8 \mathrm{~m}(8.5 \mathrm{~m}$ for SW winds that influence somewhat less the harbour sites). It is interesting to note that maximum measured significant wave heights during the last decade in the northern Baltic Proper were twice $7.4 \mathrm{~m}$ in December, 1999, whereas an even higher value $(7.7 \mathrm{~m})$ was measured on 14.01.1984 [ $\left.{ }^{23}\right]$.

The wave heights in Uudepanga Bay may be somewhat overpredicted for the west winds in southern area of the bay. The model treats the southern coast of the bay as a straight line in the east-west direction. Actually, Kiipsaare Cape and Harilaiu Bank shelter to some extent the southern part of the bay from high waves. However, the Undva harbour site is located northwards from the Kiipsaare Cape and the predicted wave heights are reliable.

There are two subtle reasons of dangerous waves at Undva. The calculations were made with the use of mean water level when mean depth on Harilaiu Bank near Kiipsaare Cape is 0.5-2 m. It effectively damps waves higher than 2.5-3 m 
and in this way protects Undva harbour during west storms. SW and west storms are frequently accompanied by uncommonly high water level. Data from Vilsandi measurement site confirm that water level elevations up to $1 \mathrm{~m}$ occur frequently and elevations up to $2 \mathrm{~m}$ are possible $\left[{ }^{4}\right]$. Water depth at the Harilaiu Bank is 3-4 m during high water events and the bank no more damps waves that may directly hit the harbour constructions.

The extensive mild underwater slopes of the Harilaiu Bank may essentially change the wave field in the Uudepanga Bay during west and SW storms. Namely, waves coming from these directions turn towards the harbour site owing to topographic refraction. Refraction intensity essentially depends on the particular wave field and peculiarities of the slopes. This is the most probable reason why WAM model predicts wave heights up to $4 \mathrm{~m}$ in the Uudepanga Bay during SW storms. However, the model assumes that the slopes are perfect and apparently overestimates the refraction intensity to some extent.

Maximum wave height $(6.2 \mathrm{~m})$ occurs at Suuriku-Kuriku during NNW storms $\left(345^{\circ}\right)$ and wave heights exceed $5.5 \mathrm{~m}$ during north winds from directions $300^{\circ}-30^{\circ}$ (Fig. 4). Extreme wave heights at Suuriku-Kuriku are by $0.5-0.8 \mathrm{~m}$ less than at Undva for all winds from the NW sector due to the screening effect of the Suuriku Clint. Wave heights at Suuriku-Kuriku are somewhat higher than at Undva only during NE and east winds but are generally less than $3 \mathrm{~m}$ at both sites owing to the screening effect of Hiiumaa. Since the probability of strong NE and east winds is very small, actual extreme wave heights for the NE sector might be of the order of $2 \mathrm{~m}$. The length of fetch for NE and east winds is less than $50 \mathrm{~km}$ whereas for NE winds it is over $200 \mathrm{~km}$.

At Vaigu, only north winds from a narrow sector may generate up to $5 \mathrm{~m}$ high waves. Wave heights also achieve $4 \mathrm{~m}$ for winds from directions $330^{\circ}-45^{\circ}$. Fetch length in the case of east winds is only a few kilometers and the extreme wave heights do not exceed $1.5 \mathrm{~m}$. As different from Undva, Vaigu and SuurikuKuriku harbour sites are open to the SE direction and SE winds may create wave heights up to $1.5 \mathrm{~m}$. At Suuriku-Kuriku, Kuriku Clint southwards from the harbour protects the basins against SE winds to some extent but Vaigu is completely open to this direction. Analysis of wind fields measured at Undva Cape $\left[{ }^{13}\right]$ suggests that wind regime of the Gulf of Riga (containing an essential portion of strong SE winds) may extend to the harbour area and result in relatively high waves.

Maximum wind speed once during $50(100)$ years is $26(27) \mathrm{m} / \mathrm{s}\left[{ }^{13}\right]$ and leads to more or less uniform increase of wave heights by $3-5 \%(5-8 \%)$ at the harbour sites for all directions as compared to wave heights during storms with $25 \mathrm{~m} / \mathrm{s}$.

Another basically interesting measure ("dynamic" representation) of the sea state at different harbour sites is the directional distribution of extreme wave heights constructed on the basis of angular distribution of climatological extreme wind speeds. It can be easily obtained on the basis of a small number of precalculated wave fields corresponding to certain constant wind speeds provided directional distribution of extreme wind speeds is known. Linear approximation 
describes well the actual sea state since extreme saturated wave field apparently is fetch-limited in the area in question and wave heights depend linearly on the mean wind speed.

Figure 5 demonstrates amazing anisotropy of directional distribution of extreme wave heights occurring once in 20 years at the harbour sites. The highest waves (about $6 \mathrm{~m}$ ) occur in the Uudepanga Bay during extreme NNW winds $\left(330^{\circ}-345^{\circ}\right)$. For other wind directions wave heights decrease fast but are still over $3 \mathrm{~m}$ for west winds. As different from to the traditional representation of extreme wave heights, the toughest wave regime at Suuriku-Kuriku (5.5-5.7 m, NNW winds, $330^{\circ}-345^{\circ}$ ) is not much better than in the Uudepanga Bay. However, for other winds from the western sector, wave heights at Suuriku-Kuriku are smaller than in the Uudepanga Bay. Vaigu has clearly milder wave regime than other sites. It possibly needs no breakwater in eastern direction since extreme wave heights during east storms do not exceed $1 \mathrm{~m}$. Conditionally, the same conclusion applies for Suuriku-Kuriku where extreme wave heights during NE storms are less than $2.5 \mathrm{~m}$.

\section{TOPOGRAPHIC WAVE ANOMALIES}

An amazing feature of the nested high-resolution model is that a number of wave regime anomalies become evident in the investigated area. Apart from minor fluctuations of isolines of significant wave heights at open sea, four regions with anomalously high waves can be distinguished in the area. Two are located near Hiiumaa and are associated with shallow water areas at Neupokojev Bank and Koroljov/Puumetsa Bank. Wave heights in these areas are 0.5-1 m higher than at open sea. A minor anomaly is located next to Suuriku Clint where in an area of $3 \times 1 \mathrm{~km}$ wave heights may increase up to $7.2 \mathrm{~m}$ during extreme

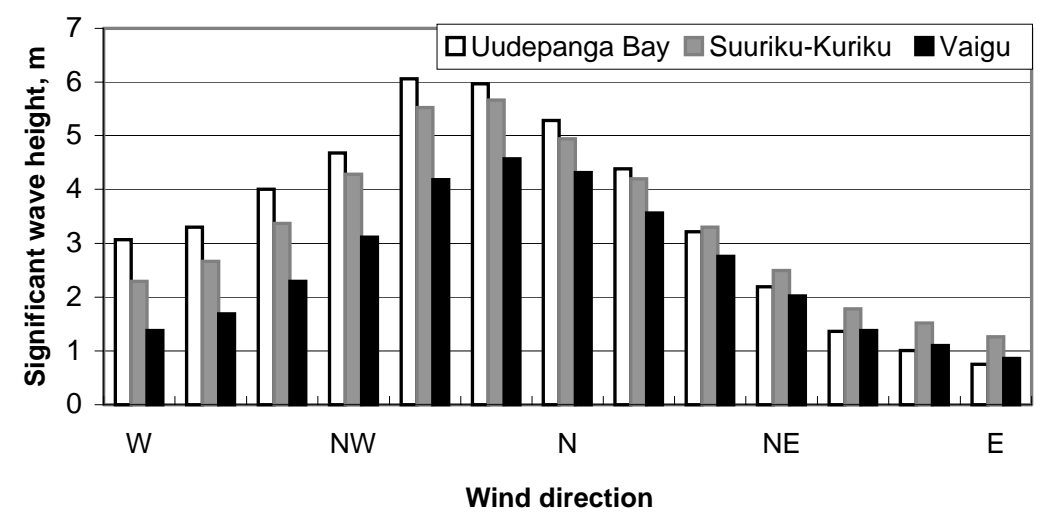

Fig. 5. Directional distribution of the extreme significant wave height once during 20 years at the harbour sites. 
north or NW storms whereas open sea wave heights are about $6 \mathrm{~m}$. Most probably, this anomaly does not exist in reality since the underwater slope in this area contains an abrupt step, but WAM model thinks it is regular. Evidently, a surf zone will emerge in this area instead of abnormally high waves.

The strongest and the most extensive anomaly with remarkably high waves occurs in the area of Harilaiu Bank (Fig. $2^{*}$ ). WAM model predicts in this area wave heights up to $10.5 \mathrm{~m}$ whereas open sea wave heights do not exceed $8 \mathrm{~m}$. Since wave period does not increase in the anomaly area, waves are steeper than open sea waves and much more dangerous to ships.

The anomaly becomes evident only during very strong winds. Its amazing property is that it emerges very fast in a certain phase of extreme storms. The anomaly does not emerge if wind speed is under $20 \mathrm{~m} / \mathrm{s}$ or if wave heights are well below $5 \mathrm{~m}$. Even if wind is stronger, in the beginning of a storm the anomaly is not present. If wind speed exceeds $20 \mathrm{~m} / \mathrm{s}$ during a longer time interval, starting from a certain instant wave heights in a certain area increase fast as compared to the open sea. Within 1-2 h, wave heights increase up to 8-10 m and exceed open sea wave heights by $2 \mathrm{~m}$ (Fig. 6). The existence of the anomaly and the exact location of the highest waves essentially depend on the particular wind speed, direction, and duration.

The anomalies emerge owing to topographic refraction of surface waves, typically resulting in the tendency of wave crests to become parallel to the bottom isolines (equivalently, wave rays bend towards shallower water). If waves propagate above a regular sea mountain, they tend to converge. The effect resembles focusing of light rays by an optical lens. It becomes evident only if the slopes of the sea mountain are regular and mild, otherwise waves break or lose their energy during interaction with bottom inhomogeneities. Underwater slopes of the Harilaiu Bank are both mild and regular, and wave energy concentration in certain areas is likely.
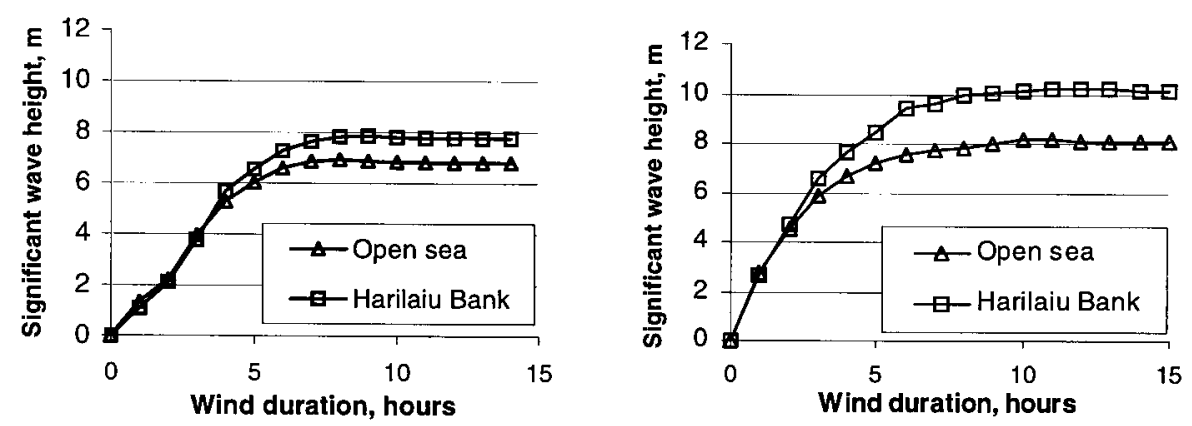

Fig. 6. Significant wave height at open sea and in the area of the Harilaiu Bank for west (left) and NW (right) winds $25 \mathrm{~m} / \mathrm{s}$. 


\section{DISCUSSION}

One might always argue whether the actual wave heights in the vicinity of the harbour sites can be that high or low. There is no definite answer to that question until in situ wave measurements will be performed. WAM model frequently underpredicts wave heights during short but intense storms $\left[{ }^{18}\right]$. One of the possible reasons for that is that the model has been calibrated for typical wind conditions - it means that both wind speed and direction fluctuate to some extent. The analysis of wind fields in the Baltic Proper shows that directionally uniform storms frequently occur in this area $\left[{ }^{13}\right]$. Thus extreme wave regimes discussed above should be interpreted as a lower boundary of actual values.

The performed analysis suggests that Undva harbour site evidently will have the toughest wave regime since it is open to the dominating winds. A positive feature is that the site is protected against north winds that are the strongest in the area in question. Although north winds may create very high waves at open sea near Suuriku-Kuriku, the harbour constructions evidently will damp waves coming from this direction. NE and east winds are infrequent and apparently will cause no problems. Probability of encountering major navigation problems is comparable at Undva and Suuriku-Kuriku. Wave regime is the mildest near Vaigu. However, it should be emphasized that comparison of the harbour sites on the basis of a single parameter (sea state relatively far from the sites) is unreliable. Indeed, detailed studies of wave transformation in the coastal zone and wave climate in the harbour basins $\left[{ }^{17}\right]$ suggest that Suuriku-Kuriku might be even a better site than Vaigu.

There are two delicate mechanims that may cause major danger to ships owing to the possible wave height anomalies, in particular, to the remarkable anomaly on Harilaiu Bank. A large increase of wave energy at that location may be expected suggesting that waves will break. What exactly happens cannot be resolved without in situ measurements (since both kinetic description and geometrical optics fail) but the presence of an extensive surf zone at the major ship lane is fairly inconvenient.

Another mechanism is connected with wave refraction due to wave-current interactions and bottom refraction. Most probably, strong currents will be generated near the anomaly area. The wave rays generally turn and the wave height may increase in certain areas. Interaction of waves and currents is most exciting when waves propagate against currents whereas for sufficiently large currents, wave propagation is prohibited and wave reflection occurs $\left[^{24}\right]$. The most dramatic outcome happens if wave rays touch each other and form a caustic. In such locations, wave energy may be reflected in the form of freak waves with extremely steep profile $\left[{ }^{25}\right]$. Recent theoretical studies suggest that freak waves created by this mechanism may frequently occur in certain areas $\left[{ }^{26}\right]$. Dynamically, bottom refraction of surface waves is equivalent to refraction of waves on spatially varying currents and may also result in the generation of freak waves. 
Thus areas with anomalously high wave energy probably serve as a source of secondary surface waves. It is unclear how far they can propagate from the anomaly area but even the formal possibility of occurrence of freak waves near harbour sites should make navigation experts anxious. Although anomalies with considerable amplitude occur only during extreme storms, both the Uudepanga Bay area and the ship lane next to Harilaiu Bank should be closed for navigation if wind speed exceeds $20 \mathrm{~m} / \mathrm{s}$ or wave heights at open sea exceed $5 \mathrm{~m}$.

Regarding Undva harbour site, the most dangerous wave regime evidently occurs if extreme west storm is accompanied by a high water level. In this case, Harilaiu Bank does no more protect the harbour area. Since the harbour basins are open to the western direction $\left[{ }^{14,17}\right]$, even relatively short high water level during west storms may result in a major danger to anchored ships. A possibility would be to close the harbour or some of its basins for periods when high water levels are probable.

\section{ACKNOWLEDGEMENTS}

This study has been performed in the framework of hydrodynamical and geological investigations of the possible locations of the Saaremaa deep harbour, financed by the Estonian Centre of Environment Studies, Ministry of Environment, and partially supported by the Estonian Science Foundation (grant No. 4025). The author is grateful to S. Zilitinkevich and M. Mohr (Department of Meteorology, Uppsala University), and to T. Kõuts for presenting wind data. Implementation of the WAM model was mainly performed when the author was visiting the Department of Meteorology, Uppsala University, as a Visby Fellow.

\section{REFERENCES}

1. Krasitski, V. P. and Monin, A. S. Phenomena on the Ocean Surface. Gidrometeoizdat, Leningrad, 1986 (in Russian).

2. Komen, G. J., Cavaleri, L., Donelan, M., Hasselmann, K., Hasselmann, S., and Janssen, P. A. E. M. Dynamics and Modelling of Ocean Waves. Cambridge University Press, Cambridge, 1994.

3. Rzheplinsky, G. V. and Brekhovskikh, Yu. P. (eds.). Wave Atlas for Gulf of Finland. Gidrometeoizdat, Leningrad, 1967 (in Russian).

4. Kõuts, T. and Laanearu, J. Variability of currents in bays of Tagalaht and Uudepanga. Proc. Estonian Acad. Sci. Eng., 2001, 7, 126-140.

5. Tolman, H. L. The influence of unsteady depths and currents of tides on wind wave propagation in shelf seas. J. Phys. Oceanogr., 1990, 20, 1166-1174.

6. Holthuijsen, L. H. and Tolman, H. L. Effects of the Gulf Stream on ocean waves. J. Geophys. Res., 1991, C96, 12755-12771.

7. Hubbert, K. P. and Wolf, J. Numerical investigation of depth and current refraction of waves. J. Geophys. Res., 1991, C96, 2737-2748.

8. Rosenthal, W. Energy exchange between surface waves and motion of sediments. J. Geophys. Res., 1978, C83, 1980-1982. 
9. Forristall, G. Z. and Reece, A. M. Measurements of wave attenuation due to a soft bottom: the SWAMP experiment. J. Geophys. Res., 1985, C90, 3376-3380.

10. Hsiao, S. V. and Shemdin, O. H. Interaction of ocean waves with a soft bottom. J. Phys. Oceanogr., 1980, 10, 605-610.

11. Yamamoto, T. and Tori, T. Seabed shear modulus profile inversion using surface (gravity) wave-induced bottom motion. Geophys. J. Roy. Astr. Soc., 1986, 85, 413-431.

12. Soomere, T. and Keevallik, S. Anisotropy of moderate and strong winds in the Baltic Proper, Proc. Estonian Acad. Sci. Eng., 2001, 7, 35-49.

13. Soomere, T. Extreme wind regimes and spatially uniform wind events in the Baltic Proper. Proc. Estonian Acad. Sci. Eng. Forthcoming.

14. Elken, J., Soomere, T., Kask, J., Kõuts, T., Liiv, U., Perens, R., and Rõõm, R. Saaremaa süvasadama võimalike asukohtade hüdrodünaamilised ja geoloogilised uuringud. Eesti Mereinstituut, Tallinn, 2000.

15. Elken, J., Kask, J., Kõuts, T., Liiv, U., Perens, R., and Soomere, T. Hydrodynamical and geological investigations of possible deep harbour sites in north-western Saaremaa Island: Overview and conclusions. Proc. Estonian Acad. Sci. Eng., 2001, 7, 85-98.

16. Booij, N., Ris, R. C., and Holthuijsen, L. H. A third-generation wave model for coastal regions. 1. Model description and validation. J. Geophys. Res., 1999, C104, 7649-7666.

17. Liiv, T. and Liiv, U. Saaremaa deep harbour layout design and computer simulation of the wave climate and sediment transport. Proc. Estonian Acad. Sci. Eng., 2001, 7, 174-192.

18. Tuomi, L., Pettersson, H., and Kahma, K. Preliminary results from the WAM wave model forced by the mesoscale EUR-HIRLAM atmospheric model. Report Series of the Finnish Institute of Marine Research, Helsinki, 1999, 40, 19-23.

19. Elken, J. Modelling of coastal circulation and oil drift at possible deep harbour sites, northwestern Saaremaa Island. Proc. Estonian Acad. Sci. Eng., 2001, 7, 141-156.

20. Seifert, T., Kayser, B., and Tauber, F. Bathymetry Data of the Baltic Sea. Baltic Sea Research Institute, Warnemünde, 1995.

21. Handbook of Climate of USSR, vol. 4: Estonian SSR, part 3: Wind. Gidrometeoizdat, Leningrad, 1966 (in Russian).

22. Troen, I. and Petersen, E. L. European Wind Atlas. Riso National Laboratory, Roskilde, 1989.

23. Kahma, K. December 1999 was a time of exceptionally rough seas on the Baltic. Report Series of the Finnish Institute of Marine Research. Annual Report 1999. Helsinki, 2000, 8.

24. Shyu, H. J. and Phillips, O. M. The blockage of gravity and capillary waves by longer waves and currents. J. Fluid Mech., 1990, 217, 115-141.

25. Shyu, J.-H. and Tung, C.-C. Reflection of oblique waves by currents: Analytical solutions and their applications to numerical computations. J. Fluid Mech., 1999, 396, 143-182.

26. White, B. S. and Fornberg, B. On the chance of freak waves at sea. J. Fluid Mech., 1998, 355, $113-138$.

\section{LAINETUSREŽIIMII JA -ANOMAALIAD SAAREMAA LOODEPIIRKONNA LÄHEDUSES}

\section{Tarmo SOOMERE}

On analüüsitud lainevälja omadusi Saaremaa süvasadama kolme võimaliku asukoha lähistel tavaliste (tuule kiirus ligikaudu $15 \mathrm{~m} / \mathrm{s})$ ja ekstreemsete $(25 \mathrm{~m} / \mathrm{s}$ ) tormide puhul. Lainete parameetrid on arvutatud tuule konstantse kiiruse ja suuna jaoks lainemudeli WAM abil lähtudes tuule kiiruse jaotusest ilmakaarte järgi. Kõige keerukam on lainetusrežiim Undva sadamakohas Uudepanga lahes, kus üle $3 \mathrm{~m}$ kõrguste lainete esinemise tõenäosus on $1 \%$. Suuriku-Kuriku sadama- 
koha lainetusrežiim on mõnevõrra soodsam (üle $3 \mathrm{~m}$ lainete tõenäosus $0,6 \%$ ) ning Vaigu on lainetuse seisukohalt parim $(0,13 \%)$. Lainekõrguse jaotus erinevatest suundadest puhuvate ekstreemsete tuulte puhul on väga ebaühtlane. Kõrgeimad lained esinevad NNW tormidega. Hästi tugevate tuulte korral on tõenäoline suure lainetusanomaalia tekkimine Harilaiu peenra kohal. See võib osutuda laevadele üliohtlikuks. 